\title{
PERCEPTION OF THE NATIONAL ENTREPRENEURSHIP CONDITIONS - DIFFERENCES ACROSS TIME AND EXPERT SPECIALIZATION
}

Sanja Pfeifer, Slavica Singer, Nataša Šarlija, Sunčica Oberman Peterka

\section{Abstract}

Creating an external context that will have nourishing effect on the entrepreneurial activities seems to be timely, path and location dependent process. The systemic explorations of the national entrepreneurial context (environment) are still relatively underrepresented. The paper explores strengths and weaknesses of the national entrepreneurship conditions in Croatia and how stable these conditions are in the longer time frame. The aim of the study is to provide more detailed insight on the differences in perceptions among experts engaged in Global Entrepreneurship Monitor (GEM) and along the time. Findings indicate deterioration of the national entrepreneurial conditions in Croatia. Experts' perceptions of national entrepreneurial conditions diverge between experts who have and those who do not have prior entrepreneurial experiences. The time also matters - perceptual difference in evaluating the quality of national entrepreneurship conditions is observed across 2015-2018.

Keywords: GEM NES dataset, entrepreneurship framework conditions, perception differences, expert's specialization, longitudinal multidimensional analysis

JEL Classification: $M 13,043,052, D 21, P 27, Z 13$

\section{INTRODUCTION}

Individual attitudes, aspirations, perceived opportunities or ventures are consequences of the specific environment. Therefore, environmental factors as well as entrepreneurial actors, play important roles in enhancing entrepreneurship and consequently - economic development. However, creating an environment that will have nourishing effect on the individual entrepreneurial decisions seems to be timely, path and location dependent process.

Sanja Pfeifer, PhD (corresponding author) Professor

Faculty of Economics in Osijek, J.J. Strossmayer University of Osijek

E-mail: sanja.pfeifer@efos.hr

Address:Trg Lj. Gaja 7, 31000 Osijek, Hrvatska ORCID: 0000-0002-7394-3080

Slavica Singer, $\mathrm{PhD}$

Professor Emeritus

UNESCO Chair of Entrepreneurship Education

J.J. Strossmayer University of Osijek

E-mail: singer@efos.hr

ORCID: 0000-0001-7205-1403

Nataša Šarlija, PhD

Professor

Faculty of Economics in Osijek,

J.J. Strossmayer University of Osijek

E-mail: natasa.sarlija@efos.hr

ORCID: 0000-0003-2600-9735

Sunčica Oberman Peterka, PhD

Professor

Faculty of Economics in Osijek,

J.J. Strossmayer University of Osijek

E-mail: suncica.oberman.peterka@efos.hr

ORCID: 0000-0001-9831-4523 
Growing number of scholars, policy makers and practitioners are interested in mapping wide range of relevant environmental factors that enhance opportunity recognition, entrepreneurial actions and outcomes. In recent discussion about the entrepreneurship capacity of a country, the concept of the entrepreneurial ecosystem is introduced aiming to differentiate between the entrepreneurial contexts on the sub-national level from the context on the national level (labelling it as an environment). In both cases, the focus is on inter-connectedness among different stakeholders and relevant factors important for enhancing new and growth-oriented entrepreneurial activity. The difference is in spatial dimension of the influence - national or sub-national. National level of influence covers stakeholders' activities that horizontally affect all actors in a country (e.g. government policies toward the regulatory framework). Sub-national level (in recent scholar discussions usually described as entrepreneurship eco-system) refers to the availability of conditions more specific to the entrepreneurship activity in a region (e.g. the educational infrastructure in a region, or availability of services of an incubator / accelerator, quality of communication infrastructure, etc.).

Since our study deploys the Global Entrepreneurship Monitor (GEM) conceptual framework of entrepreneurship enhancers - a set of twelve entrepreneurship framework conditions, the analysis is focused on national level of the context in which entrepreneurship activity is performed.

GEM is a multinational, multilevel, longitudinal study of the entrepreneurial activity around the world, based on collecting primary data. In twenty years, GEM has become important provider of empirical data of individual entrepreneurial activity, attitudes, and aspirations across different countries. In addition, it offers an insight into the perception of the quality of environmental / contextual factors that are relevant for entrepreneurial behaviour in a particular country or region. Empirical evidence stemming from GEM, particularly related to multinational and multiregional (world, national or cross-border level) entrepreneurship environment has been growing. However, the systemic explorations of the national entrepreneurial conditions are underrepresented.

In order to contribute to closing that gap, our study explores strengths and weaknesses of the Croatian entrepreneurial framework conditions. In addition, this study aims to explore differences in expert perception across time and their field of expertise. The paper starts with the brief description of the institutional approach in entrepreneurship research. The previous research review is focused on the GEM based research related to entrepreneurship framework conditions in order to justify research questions and hypothesis development. The article then presents methodology and results. Finally, we discuss the major findings and offer conclusion.

\section{THEORETICAL FOUNDATION}

Given the importance of the new venture creation for economic growth and creation of employment (Thurik and Wennekers 2004) it is no surprise that there is a growing interest of scholars and practitioners for finding better ways to enhance entrepreneurial activities. Understanding the importance of the dynamic changes in the environment in which an individual is performing entrepreneurial activity requires implementation of the institutional approach to social and economic development (North 1990 and 2005). The institutional approach stresses interconnectedness among actors / institutions and the interaction between the environment and an individual, which influences the individual's decisions related to entrepreneurial activity. This approach is very valuable in revealing the constraining and enabling effects of formal and informal rules on the behaviour of an individual (DiMaggio 1998). Bringing together market and behavioural perspectives, the institutional approach provides a very productive framework for researching variety of interrelationships related to entrepreneurship activities, in a system's theory manner. Majority of the research is focused on the entrepreneurship context on the national level, or is neutral toward the spatial feature of the context. Autio et al. (2014) were using this approach in examining the contextual influences on entrepreneurial activities, specifically on developing innovative ventures. More recently, one strain of the institutional research related to entrepreneurship is taking a step forward in differentiating between national and sub-national level (ecosystem) of entrepreneurial context.

Respecting needs for supporting economic and social development on sub-national level, Stam (2015) identified entrepreneurship (sub-national) ecosystem, including systemic (networks, leadership, finance, knowledge, talent, support services) and framework conditions (formal institutions, culture, physical infrastructure, demand). Stam and Spigel (2016, p. 2) brought a quality perspective in the updated definition of the entrepreneurial ecosystem "as the set of interdependent actors and factors coordinated in such a way that they enable productive entrepreneurship within a particular territory" by emphasising productive type of entrepreneurship. In this line of thinking 
is the expectation expressed by Audretsch and Belitski (2017, p. 1031) who see an entrepreneurial ecosystem as a set of relevant external or environmental factors that "influence identification and commercialization of entrepreneurial opportunities".

Sternberg, Bloh, and Coduras (2019) are offering a framework to measure entrepreneurial ecosystem at the regional level. They used Stam's (2015) approach and developed a composite index for measuring the effectiveness of the entrepreneurial ecosystem, and a portfolio of indices measuring each component of the ecosystem. Based on this research, in 2020 the GEM consortium introduced a new diagnostic tool Entrepreneurial Ecosystem Quality Composite Index (ESI), for measuring the quality of the entrepreneurial ecosystem, on the level of cities or regions in a country.

In order to avoid misunderstandings, in this paper the term entrepreneurship environment will be used for the national level, and the entrepreneurship ecosystem for sub-national level, when discussing the context in which an individual is performing any kind of entrepreneurial activity. When using GEM data, we will refer to Entrepreneurship Framework Conditions for identifying the entrepreneurship environment (national level).
Since the research presented in this paper is using Global Entrepreneurship Monitor (GEM) conceptual framework and the GEM data, an overview of research interests based on GEM will be presented as a platform for identifying a research problem and the research questions.

\subsection{Global Entrepreneurship Monitor- Conceptual Framework}

Global Entrepreneurship Monitor (GEM) conceptual framework (Bosma et al. 2020, p. 24) suggests that different types of entrepreneurial activity (reflecting different phases: preparing, starting or growing a venture) respond differently to a set of entrepreneurial contextual factors. In addition, GEM proposes that entrepreneurial framework conditions (EFCs) indicate country's ability to promote and support entrepreneurial behaviour. Building upon the prior conceptualization by Reynolds et al. (2000) as well as Levie and Autio (2008), the GEM entrepreneurial framework conditions (GEM EFCs) include factors ranging from access to the sources of finances to sociocultural norms (see table 1). Latest development in the GEM EFCs model includes the measurement dimension by introducing

Table 1. GEM entrepreneurship framework conditions

\begin{tabular}{ll}
\hline $\begin{array}{l}\text { Entrepreneurship framework } \\
\text { condition (EFC) }\end{array}$ & Description \\
\hline Entrepreneurial Finance & $\begin{array}{l}\text { Availability of financial resources for new and growing firms (including eq- } \\
\text { uity, debt, grants and subsidies, private investors, etc.) }\end{array}$ \\
\hline $\begin{array}{l}\text { Government Policies: Support and } \\
\text { Relevance }\end{array}$ & The extent of public policies focused on supporting new and growing firms \\
\hline $\begin{array}{l}\text { Government Policies: Taxes and } \\
\text { Bureaucracy }\end{array}$ & $\begin{array}{l}\text { The extent to which taxes and regulations do not harm new and growing } \\
\text { firms }\end{array}$ \\
\hline Government Entrepreneurship Programs & The presence of programs focused on enhancing new and growing firms \\
\hline $\begin{array}{l}\text { Entrepreneurial Education at } \\
\text { School Stage }\end{array}$ & $\begin{array}{l}\text { Attention given to building creativity, self-confidence, or basic understand- } \\
\text { ing of market of entrepreneurial principles in primary and secondary schools }\end{array}$ \\
\hline $\begin{array}{l}\text { Entrepreneurial Education at Post } \\
\text { School Stage }\end{array}$ & $\begin{array}{l}\text { Availability of programs that prepare for starting and managing new or } \\
\text { growing firms at all types of higher educational institutions including univer- } \\
\text { sities, colleges, vocational or professional schools }\end{array}$ \\
\hline R\&D Transfer & $\begin{array}{l}\text { Availability of new knowledge, and affordability of new technologies for new } \\
\text { and growing firms }\end{array}$ \\
\hline Commercial and Professional Infrastructure & $\begin{array}{l}\text { Availability and affordability of business suppliers, contractors, consultants, } \\
\text { legal, accounting and banking services }\end{array}$ \\
\hline Internal Market Dynamics & Perception of dramatic changes in markets \\
\hline Internal Market Burdens or Entry & The extent to which new and growing firms are free to enter existing markets \\
Regulation & $\begin{array}{l}\text { Ease of access to communication, utilities, transportation, land and space at a } \\
\text { price that does not discriminate against new and growing firms }\end{array}$ \\
\hline Physical Infrastructures & $\begin{array}{l}\text { The extent to which national culture supports individual success, self-suffi- } \\
\text { ciency, risk taking, innovativeness and individual responsibility }\end{array}$ \\
\hline Cultural and Social Norms &
\end{tabular}

Source: Adopted from gemconsortium.org 
a single indicator to reflect the health of a country's twelve entrepreneurship framework conditions. The composite indicator - National entrepreneurship context index (NECl) is calculated as the weighted average of EFC importance and EFC quality and enables ranking of the GEM countries by the health of their respective entrepreneurship frameworks (supporting or hindering the entrepreneurship activity).

\subsection{Previous research based on GEM}

The GEM research related to the exploration of the environmental factors - encapsulated by the term entrepreneurship framework conditions (EFCs) - shows wide range of focuses. The table 2 presents recent scientific articles published over last 15 years, sorted by primary focus and respective reference.

Literature review provides evidence of the several streams and levels of aggregation in the explorations related to the entrepreneurship framework conditions. One stream of research indicates that entrepreneurship environment is significantly associated with various types of entrepreneurial activities in terms of business start-ups and business growth, motivation, or gender. Another stream of research is focused on exploring differences between EFCs across nations, or other types of contexts. The results of these studies indicate significant differences between ecosystems across different nations and regions. However, the empirical evidence is inconclusive and suggests positive, neutral or even negative effect for particular type of entrepreneurial behaviour. The same holds for the empirical research related to the specific EFC or inter-relationship between EFCs. Another stream of the research indicates that perception of experts in assessing the quality of entrepreneurship framework conditions may vary by expert specialization, gender, time and location.

Since there is no empirical consensus regarding the attributes, interactions or impact of framework of entrepreneurial conditions, new empirical evidence is highly welcomed (Alvarez et al. 2011). In particular, Alvarez, Urbano, and Amorós (2014) indicate the absence of the case studies and Amorós et al. (2013) call for more explorations of national experts' datasets, whereas Sternberg, Bloh and Coduras (2019) call for more comparisons of entrepreneurial ecosystems

Table 2. Literature review on GEM based research

\begin{tabular}{|c|c|c|}
\hline Topic & Principal research focus & Author \\
\hline \multirow[t]{5}{*}{ Entrepreneurial conditions } & Influence on entrepreneurial activity (EA) & $\begin{array}{l}\text { De Clercq, Lim, and Oh (2013) } \\
\text { Sampaio et al. (2018) }\end{array}$ \\
\hline & Impact on prevalence of male/female EA & $\begin{array}{l}\text { Verheul, Van Stel, and Thurik (2006) } \\
\text { Hechavarria and Ingram (2019) }\end{array}$ \\
\hline & $\begin{array}{l}\text { Impact on prevalence of opportunity or } \\
\text { necessity driven EA }\end{array}$ & Terjesen and Amorós (2010) \\
\hline & $\begin{array}{l}\text { Relationship with different stages of EA } \\
\text { (intention, nascent, early, etc.) }\end{array}$ & Teixeira et al. (2018) \\
\hline & Effect on growth aspiration (innovation) & Savosh (2019) \\
\hline \multirow{4}{*}{$\begin{array}{l}\text { Entrepreneurial conditions } \\
\text { comparisons }\end{array}$} & Cross national & Kitsios and Sitardis (2017) \\
\hline & $\begin{array}{l}\text { Different stages of economic develop- } \\
\text { ment (factor driven, efficiency driven, or } \\
\text { innovation driven) }\end{array}$ & Alvarez et al. (2011) \\
\hline & Specific contexts (transitional countries) & Chepurenko (2017) \\
\hline & Specific geographic regions & $\begin{array}{l}\text { Tominc and Rebernik (2007) Andonova, } \\
\text { Nikolova, and Dmitrov (2019) }\end{array}$ \\
\hline $\begin{array}{l}\text { Components of the national } \\
\text { entrepreneurship framework } \\
\text { conditions (EFCs) }\end{array}$ & $\begin{array}{l}\text { Entrepreneurship education } \\
\text { Knowledge transfer } \\
\text { Intellectual property rights }\end{array}$ & $\begin{array}{l}\text { Fellnhofer and Kraus (2015) } \\
\text { De Clercq and Arenius (2006) } \\
\text { Autio and Acs (2010) }\end{array}$ \\
\hline \multirow[t]{3}{*}{$\begin{array}{l}\text { Differences in expert } \\
\text { perceptions of EFCs }\end{array}$} & Expert specialization & $\begin{array}{l}\text { Lee and Wong (2004) } \\
\text { Correia et al. (2016) }\end{array}$ \\
\hline & Location (core vs. peripheral) & $\begin{array}{l}\text { Felzensztein, Gimmon, and Aqueveque et al. } \\
(2013)\end{array}$ \\
\hline & Time & Silva, Correia, and Duarte (2018) \\
\hline
\end{tabular}

Source: Authors' creation 
across time and countries. In addition, Fellnhofer and Kraus (2015) indicate that significant amount of entrepreneurship research relies on the perception rather than 'hard' indicators - what is understandable not only because of strong behavioural dimension of the entrepreneurship activity, but also because perceptual data are value adding to evaluation of any activity. However, little is known about existence or nature of perceptual differences and their effect on interpretation of entrepreneurship framework conditions (Lee and Wong 2004).

\subsection{National entrepreneurship conditions - The context of Croatia}

Our study explores the case of Croatia's entrepreneurship environment. Croatia is a member of the EU from 2013, and from 2007 belongs to high income economies (according to the World Economic Forum classification of the stages of economic development the Croatia has not been classified as the high income country only in 2016). GEM 2018 survey reports that Croatia's EFCs system (using GEM wording for entrepreneurship environment, context, entrepreneurship ecosystem on national level) is ranked as $53^{\text {rd }}$ among 54 countries participating in the survey (Bosma and Kelley 2019). Comparison of nine countries in 2016 (Argentina, Bulgaria, Croatia, Cyprus, Greece, Ireland, FYROM, Portugal, Turkey) ranked Croatia's EFCs system as the least sufficient to enhance entrepreneurial activities (Kitsios and Sitaridis 2017). Similarly, in the cluster analysis of 24 European national EFCs systems Croatia belongs to the lowest ranked cluster during 2010-2016 (Silva, Correia, and Duarte 2018). In contrast, the level of total early stage entrepreneurial activity (percentage of adults aged 18-64 who started a venture in last 42 months) in Croatia has been increasing (Singer et al. 2019). These evidence calls for more detailed insights into following questions: What are (if any) the comparative strengths or weaknesses of Croatia entrepreneurial conditions? What kind of entrepreneurial activity Croatian entrepreneurial conditions sustains?

We assume that similar research question may be of interest for various countries searching for the new ways of enhancing their entrepreneurial environment.

\subsection{The perceptual differences}

The GEM as well as many other surveys rely on the perceptions rather than 'hard' data in their exploration of the entrepreneurship activity or environmental factors. The quality of the EFCs is evaluated by its key stakeholders such as entrepreneurs, investors, venture capitalists, educators, researchers, policy makers or professional services providers. The proverbial saying that "What one sees depends on where one sits" may provide simple reasoning for presumption how different groups of specialists have different reference frames that influence their interpretation and assessment of EFCs. Cognitive approach to entrepreneurship indicates that perception is subjective interpretation of reality resulting mainly from the prior experiences, frame of references, and interest (Liñán, Santos, and Fernández 2011).

Several studies investigate these issues using GEM data. Lee and Wong (2004) found differences in perception of the EFCs among the actors playing the role in entrepreneurship environment on government support, feasibility of market entry and financial support. The policy makers, for example, perceive government support, access to finances, or market entry feasibility more favourably due to their responsibility and selfinterest in policies related EFCs. Correia et al. (2016) reported that entrepreneurs perceive lower quality of the access to finances, government policies and programs and education. In line with that reasoning, we assume that experts who are actual entrepreneurs have more specific and more sophisticated demands and expectations on the sources of entrepreneurial finances. Therefore, their perception is more critical in comparison to policy makers, investors, educators. We suppose the similar expectation holds true for all other entrepreneurial framework conditions. Such biases exist always in perceptual evaluations and the challenge is how to reduce them. Experts who are entrepreneurially active or have prior entrepreneurial experiences are more critical toward the EFCs than the experts of other specialization. Therefore, we propose that:

$\mathrm{H} 1$ : There are differences in perception of the EFCs across specialization of the experts participating in EFCs evaluation.

Entrepreneurial ecosystems on any level (national, regional), alike the natural ones, are dynamic systems. This allows the evolution of all their components (Segui-Mas, Jimenez-Arribas, and Tormo-Carbo 2018), which can happen at different path and different dynamics, sometimes not coherently. The evolving character of the ecosystems should result in differences in the perception of EFCs across years. Correia et al. (2016) report significant differences in perception of the EFCs in two consecutive years among GEM NES experts. Croatia has been experiencing prolonged economic crisis during the 2009-2014, promising growth of GDP during 2015-2016 and the growth slowdowns 
in 2017-2019 (World Bank 2020).

We expect that such changes in the GDP growth rates should be reflected in the perception of framework conditions. Our presumption is as follows:

$\mathrm{H} 2$ : There are differences in perception of the EFCs across 2015-2018.

\section{METHODOLOGY}

GEM provides three sets of primary data: the adult population survey (APS dataset), the national expert survey (NES dataset), and standardized cross-national dataset. Adult population survey (APS) collects data on individual entrepreneurial activity of the adult population, 18-64 years old. Annually, at least 2000 adults are administered in the APS in each of the participating countries. National Expert Survey (NES) collects experts' opinions and perceptions related to the entrepreneurship framework conditions. Each year at least 36 experts recognized for their professional knowledge and expertise related to different components of the entrepreneurship environment are recruited from the pool of experts identified through years, and rotated on yearly basis (therefore those experts cannot be considered as a panel). They assess the quality of the entrepreneurship framework conditions for their respective country. Our study combines GEM 2018 NES NATIONAL LEVEL and GEM 2018 NES CROATIA INDIVIDUAL LEVEL datasets in four consecutive years (2015-2018). The former dataset enables comparison of Croatia with other countries, while the later allows more detailed perceptual insight in potential strengths or weaknesses of national entrepreneurship conditions. Furthermore, GEM Adult Population
Survey (APS) is deployed to extract the information of entrepreneurial activity in Croatia and comparable countries.

\subsection{The instruments and variables}

The dataset GEM 2018 NES CROATIA INDIVIDUAL LEVEL is used to assess the variability of the perception across expert specialization and time. The instrument for collecting relevant information - National Expert Survey (NES) is on-line questionnaire self-administered by entrepreneurship experts. The questionnaire comprises 54 statements grouped in twelve constructs reflecting the GEM conceptual model explained earlier. We explored scores for each item in a specific EFC - e.g., for the component Entrepreneurial Finance we have calculated average score of each individual items in financing (A01-A08). Table 3 presents the EFC name, code, number and codes of the items in the EFCs. The scores range from 1-highly insufficient /inadequate to 9- highly sufficient /adequate (Likert scale).

Information on the expert specialization is extracted from GEM 2018 NES CROATIA INDIVIDUAL LEVEL dataset as a set of five dummy variables (NES SPE_1- NES_SPE5). Those variables were transformed in two independent samples of participating experts. One group includes experts who are actual entrepreneurs or have prior entrepreneurial experience (SPE1) whereas other group includes all other experts (SPE_2: Investors/Financers/Bankers; SPE_3: Policy makers; SPE_4: Business and Support Services providers; SPE_5: Educators, Teachers or Researchers). Table 4 presents the structure of the sample.

Table 3. Description of the independent variables- EFC constructs

\begin{tabular}{llcc}
\hline Entrepreneurship framework condition - EFC & EFC codes & $\begin{array}{c}\text { Number } \\
\text { of items }\end{array}$ & Codes of the items \\
\hline Entrepreneurial Finance & NES_A & 8 & A01-A08 \\
\hline Government Policies: Support and Relevance & NES_B1 & 3 & B01-B03 \\
\hline Government Policies: Taxes and Bureaucracy & NES_B2 & 4 & B04-B07 \\
\hline Government Entrepreneurship Programs & NES_C & 6 & C01-C06 \\
\hline Entrepreneurial Education at School Stage & NES_D1SUM & 3 & D01-D03 \\
\hline Entrepreneurial Education at Post School Stage & NES_D2SUM & 3 & D04-D06 \\
\hline R\&D Transfer & NES_ESUM & 6 & E01-E06 \\
\hline Commercial and Professional Infrastructure & NES_FSUM & 5 & F01-F05 \\
\hline Internal Market Dynamics & NES_G1SUM & 2 & G01-G02 \\
\hline Internal Market Burdens or Entry Regulation & NES_G2SUM & 4 & G03-G06 \\
\hline Physical Infrastructures & NES_HSUM & 5 & H01-H05 \\
\hline Cultural and Social Norms & NES_ISUM & 5 & I01-I05 \\
\hline Source:Author's creation & & 5
\end{tabular}

Source: Author's creation 
Table 4. Sample size according to expert specialization over the years

\begin{tabular}{cccc}
\hline & \multicolumn{2}{c}{ Expert specialization - Frequencies } & Total \\
\hline Year & $\begin{array}{c}\text { Entrepreneurs } \\
(\text { SPE_1) }\end{array}$ & $\begin{array}{c}\text { Other specialization } \\
(\text { SPE_2 - SPE_5) }\end{array}$ & \\
\hline 2015 & 16 & 24 & 40 \\
\hline 2016 & 16 & 24 & 40 \\
\hline 2017 & 18 & 24 & 42 \\
\hline 2018 & 12 & 27 & 39 \\
\hline Total & 62 & 99 & 161 \\
\hline
\end{tabular}

Source: Authors' calculations

In order to gain an insight in the relationship between the total early stage entrepreneurial activity (TEA) and the specific national EFCs system, the GEM 2018 Adult Population Survey datasets were used. We have extracted Motivational Index (MI) variable that is calculated as the ratio of improvement-driven and opportunity motivated (TEA IDO) versus necessity driven (TEA NEC) total early stage entrepreneurial activity. The higher motivational index indicates better quality of the entrepreneurial activity, due to the higher impact of improvement and opportunity driven entrepreneurs on innovation, employment and economics growth (Levie and Autio 2008). NecessityDriven Entrepreneurial Activity (TEA NEC) is calculated as a "percentage of those involved in total early stage entrepreneurial activity (TEA) who are involved in entrepreneurship because they had no better options for work. Improvement-Driven Opportunity Entrepreneurial Activity (TEA IDO) is calculated as a percentage of those involved in TEA who (i) state they are driven by opportunity as opposed to having no better options for work; and (ii) who indicate the main driver for being involved in this opportunity is being independent or increasing their income, rather than just maintaining their income" (Bosma and Kelley 2019, p. 138).

\subsection{Methods}

In order to analyse differences in perceptions related to entrepreneurship framework conditions according to experts' specialization (entrepreneurs vs other specialization related to entrepreneurship) and time (2015-2018), 2 way ANOVA is applied when homogeneity of variances and normality of dependent variable is fulfilled. In the cases when assumptions are not met, Scheirer-Ray-Hare test is applied.

Statistical software R (version 3.6.0) was used for data analysis.

\section{RESULTS}

\subsection{Quality of Croatian national entrepreneur ship conditions}

In order to explore the potential strengths of Croatia entrepreneurship conditions we compare Croatia with countries participating in GEM survey in 2018 (all 54 participating countries), High-income countries (32 countries) and members of the European Union (18 countries) (table 5).

Table 5. Average scores* of EFC constructs for Croatia, GEM countries, High income, and EU countries, 2018

\begin{tabular}{|c|c|c|c|c|}
\hline Entrepreneurship framework conditions (EFCs) & Croatia & GEM & High income & EU \\
\hline Entrepreneurial Finance & 3,97 & 4,29 & 4,55 & 4,73 \\
\hline Government Policies: Support and Relevance & 2,82 & 4,37 & 4,57 & 4,24 \\
\hline Government Policies: Taxes and Bureaucracy & 2,1 & 3,88 & 4,04 & 3,99 \\
\hline Government Entrepreneurship Programs & 3,29 & 4,49 & 4,82 & 4,69 \\
\hline Entrepreneurial Education at School Stage & 2,45 & 3,14 & 3,27 & 3,26 \\
\hline Entrepreneurial Education at Post School Stage & 3,71 & 4,79 & 4,85 & 4,75 \\
\hline R\&D Transfer & 2,97 & 3,95 & 4,28 & 4,20 \\
\hline Commercial and Professional Infrastructure & 3,76 & 4,90 & 5,07 & 5,19 \\
\hline Internal Market Dynamics & 5,13 & 5,27 & 5,05 & 4,87 \\
\hline Internal Market Burdens or Entry Regulation & 3,01 & 4,20 & 4,46 & 4,58 \\
\hline Physical Infrastructures & 5,51 & 6,32 & 6,63 & 6,59 \\
\hline Cultural and Social Norms & 2,74 & 4,84 & 4,84 & 4,37 \\
\hline
\end{tabular}

* Likert scale 1 (highly insufficient) to 9 (highly sufficient)

Source: GEM 2018 NES NATIONAL LEVEL, authors' calculations 
Croatia scores lag behind all scores of the high-income and EU countries participating in the GEM survey in 2018. Only Internal Market Dynamics score is higher in Croatia than in EU countries what indicates that the market is not hindering component of the entrepreneurship environment.

With regard to the strengths and weaknesses of the Croatia's EFCs, table 5 shows that access to physical infrastructure as well as internal market dynamics have average scores slightly above five. The score " 5 " indicates neutral (neither insufficient, neither sufficient) quality of EFC. Therefore, we tentatively interpret that those "somewhat sufficient" as two strengths of the Croatian EFCs. Government policies toward taxes and bureaucracy, entrepreneurial-related education at primary and secondary level as well as cultural and social norms with the lowest scores are perceived as insufficient or moderately insufficient and therefore the weakest components.

The comparisons of the same EFCs over time allow seeing if there are any changes in the perception across years. For exploring temporal changes in perception of EFCs, we have calculated their compounded annual growth rates (CAGR) (see table 6).

The quality of only two components of the entrepreneurial environment in Croatia is showing significant positive perceptual changes (Entrepreneurial Finance and Entrepreneurial Education at School Stage). Three components (Internal Market Dynamics, Physical Infrastructure and Commercial and Professional Infrastructure) are experiencing strong deterioration in the perception of their quality. It is very disturbing finding because they are among the best evaluated components. All other components with CAGR values between $-0.22 \%$ (Internal Market Burdens or Entry Regulation) and 1.81\% (Government Policies: Taxes and Bureaucracy) are not providing any significant change in the quality of the EFC.

In order to gain more insights into what type of the entrepreneurial activity (presented by the Motivational Index - ratio of improvement-driven and opportunity motivated versus necessity driven ventures) is sustained by a particular state of the EFCs we combined information on $\mathrm{NECl}$ and Motivational index across European countries participating in the GEM 2018. Figure 1 presents European countries dispersed among four quadrants according to the quality of entrepreneurship environment (NECl) and quality of early stage entrepreneurship activity (TEA). NECI values lower than five indicate unfavourable conditions, and higher than five relatively favourable conditions. High motivational index indicate higher quality of the entrepreneurial activity and the threshold is five on the scale of 0 to 10 .

Croatia is positioned into the lower left corner in a cluster where low quality of EFCs sustains only low prevalence of the improvement and opportunity driven ventures. Unlike Croatia, the Netherlands shows one of the healthiest entrepreneurship environment and percentage of the improvement or opportunity driven entrepreneurial activity is 8 times higher to ones driven by the necessity.

Table 6. Average scores* of EFCs during 2015-2018 in Croatia

\begin{tabular}{llllll}
\hline Entrepreneurship framework conditions (EFCs) & 2015 & 2016 & 2017 & 2018 & CAGR \\
\hline Entrepreneurial Finance & 3,3 & 3,79 & 4,02 & 3,97 & $6,36 \%$ \\
\hline Government Policies: Support and Relevance & 2,84 & 2,8 & 3,26 & 2,82 & $-0,24 \%$ \\
\hline Government Policies: Taxes and Bureaucracy & 1,99 & 2,18 & 2,14 & 2,1 & $1,81 \%$ \\
\hline Government Entrepreneurship Programs & 3,21 & 3,46 & 3,6 & 3,29 & $0,82 \%$ \\
\hline Entrepreneurial Education at School Stage & 1,89 & 2,47 & 2,39 & 2,45 & $9,04 \%$ \\
\hline Entrepreneurial Education at Post School Stage & 3,53 & 3,83 & 3,69 & 3,71 & $1,67 \%$ \\
\hline R\&D Transfer & 2,85 & 2,73 & 3,29 & 2,97 & $1,38 \%$ \\
\hline Commercial and Professional Infrastructure & 4,29 & 4,23 & 4,66 & 3,76 & $-4,30 \%$ \\
\hline Internal Market Dynamics & 6,08 & 5,48 & 5,79 & 5,13 & $-5,51 \%$ \\
\hline Internal Market Burdens or Entry Regulation & 3,03 & 3,26 & 3,16 & 3,01 & $-0,22 \%$ \\
\hline Physical Infrastructures & 6,46 & 6,21 & 5,94 & 5,61 & $-4,59 \%$ \\
\hline Cultural and Social Norms & 2,63 & 2,95 & 2,96 & 2,74 & $1,38 \%$ \\
\hline
\end{tabular}

* Likert scale 1 (highly insufficient) to 9 (highly sufficient)

Source: GEM 2018 NES NATIONAL LEVEL, authors' calculations 
Figure 1. Quality of national entrepreneurship framework conditions index (NECl) and motivational index of European countries

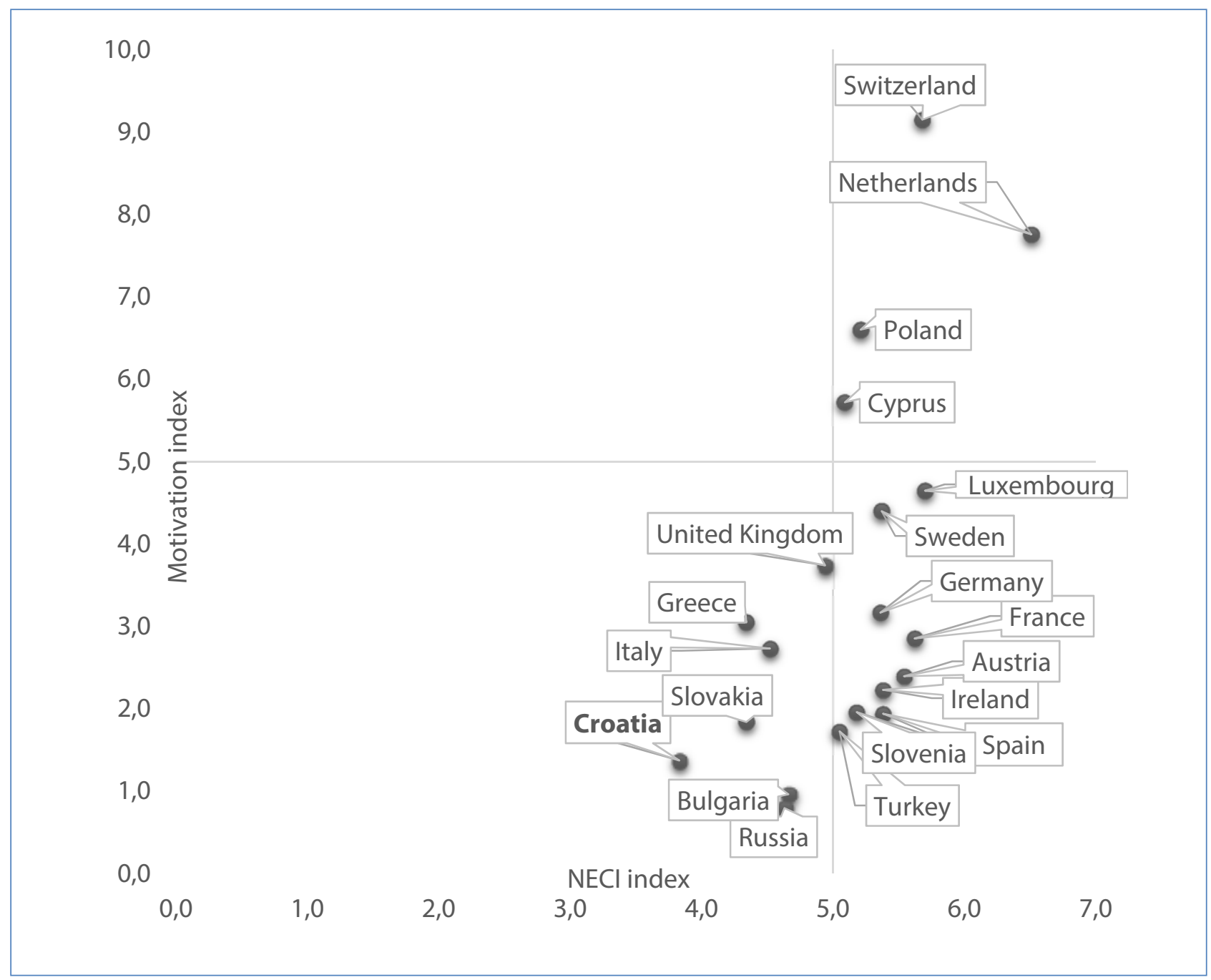

Source: GEM 2018 NES NATIONAL LEVEL, authors' creation

\subsection{Perceptual differences of experts' evaluation of $E F C S$}

In order to check if and how biased the perception of the EFCs is, we have explored whether different specialization of an expert makes any differences in the perception of the EFCs and whether the opinions have been changing over time. We have also checked if interaction effect of specialization and time is significant. Results are presented in tables 7-14 with statements where only significant differences are found.

Statistically significant differences were found in 18 out of 54 statements where most of them are connected to specialization. In only three statements both differences in opinions (related to specialization and time) were identified (two in the Entrepreneurial Finance, one in Physical Infrastructure). EFCs with the majority of significant differences are entrepreneurial finance and entrepreneurial education.

If an interaction effect between time and specialization is significant, it means that attitudes change both depending on time and on specialization simultaneously. There are only two such cases - both related to statements on venture capital and IPOs, as part of the Entrepreneurial Finance component of the national entrepreneurship environment in Croatia. 


\subsubsection{On Entrepreneurial Finance}

Access to finance is composed of different sources which availability does not always fit with the needs of new and growing firms. That is a case in Croatia confirmed by the differences in collected opinions of experts along surveyed years. The biggest difference in opinions is related to the statement if there is sufficient debt funding available for new and growing firms. Debt financing is more available than other sources, but at the same time this source is the least suitable for ventures with higher risks, like new and growing firms. Both groups (entrepreneurs and others) scored the availability of debt funding higher than any other source, with rising tendency over the observed period. Entrepreneurs on average gave lower scores $(p<0,001)$ and scores grew over time $(p=0,07)$. Both groups keep their pace of scoring trend,

Regarding sufficient funding available from professional Business Angels for new and growing firms, differences exist according to time $(p=0,065)$ - evaluation had been growing since 2015 and then dropped in 2018. Here, entrepreneurs more positively evaluate this statement than other experts. In evaluating if private lenders' funding (crowdfunding) is available for new and growing firms, entrepreneurs on average gave higher scores $(p=0,012)$ then others and scores had been growing since 2015 and then dropped in $2018(p=0,001)$.

Judgements about sufficient funding available from venture capitalists $(p=0,04)$ and through initial public offerings (IPOs) ( $p=0,078)$ for new and growing firms vary according to time and specialization. In 2015 and 2018 entrepreneurs' evaluations were lower while in 2016 and 2017 higher compared to other specialization.

Judgements about sufficient funding available from venture capitalists $(p=0,04)$ and through initial public offerings (IPOs) ( $p=0,078)$ for new and growing firms vary according to time and specialization. In 2015 and 2018 entrepreneurs' evaluations were lower while in 2016 and 2017 higher compared to other specialization.

Interaction effect of specialization and time is confirmed for the availability of other financial sources for supporting new and growing firms (venture capital, IPOs), showing that opinions are changing depending on simultaneous influence of time and specialization

Table 7. Mean values of Entrepreneurial Finance statements' evaluation /2 way ANOVA / Scheirer-Ray-Hare test

\begin{tabular}{|c|c|c|c|c|c|}
\hline & $\mathrm{A} 02$ & A05 & A06 & $\mathrm{A} 07$ & A08 \\
\hline Entrepreneurs & $3,71^{*}$ & 3,93 & 3,28 & 2,76 & $4,26^{*}$ \\
\hline Others & 5,06 & 3,63 & 3,06 & 2,73 & 3,44 \\
\hline 2015 & $4,18+$ & $3,07+$ & 2,82 & 2,65 & $2,59+$ \\
\hline 2016 & 4,13 & 4 & 2,97 & 2,55 & 3,9 \\
\hline 2017 & 4,85 & 4,13 & 3,52 & 2,89 & 4,44 \\
\hline 2018 & 5,02 & 3,77 & 3,25 & 2,91 & 4,08 \\
\hline 2015 Entrepreneurs & 3,07 & 3,31 & $2,73 \#$ & $2 \#$ & 2,88 \\
\hline 2015 Others & 4,88 & 2,91 & 2,88 & 3,04 & 2,39 \\
\hline 2016 Entrepreneurs & 3,73 & 4,5 & 3,47 & 2,8 & 4,81 \\
\hline 2016 Others & 4,38 & 3,67 & 2,67 & 2,39 & 3,29 \\
\hline 2017 Entrepreneurs & 4,17 & 4,35 & 4 & 3,57 & 5,25 \\
\hline 2017 Others & 5,39 & 3,96 & 3,17 & 2,45 & 3,87 \\
\hline 2018 Entrepreneurs & 3,83 & 3,42 & 2,6 & 2,44 & 4 \\
\hline 2018 Others & 5,56 & 3,93 & 3,5 & 3,08 & 4,11 \\
\hline
\end{tabular}

* significant according to specialization

+ significant according to years

\# significant interaction effect between specialization and year

A02: There is sufficient debt funding available for new and growing firms.

A05: There is sufficient professional Business Angels funding available for new and growing firms

A06: There is sufficient venture capitalist funding available for new and growing firms.

A07: There is sufficient funding available through initial public offerings (IPOs) for new and growing firms.

A08: There is sufficient private lenders' funding (crowdfunding) available for new and growing firms.

Source: Authors' calculations 


\subsubsection{On Government Entrepreneurship Programs}

Table 8. Mean values of Government Entrepreneurship Programs statements' evaluation /2 way ANOVA / ScheirerRay-Hare test

\begin{tabular}{ll}
\hline & C04 \\
\hline Entrepreneurs & $3,13^{*}$ \\
\hline Others & 3,79 \\
\hline 2015 & 3,05 \\
\hline 2016 & 3,68 \\
\hline 2017 & 3,82 \\
\hline 2018 & 3,59 \\
\hline 2015 Entrepreneurs & 2,81 \\
\hline 2015 Others & 3,22 \\
\hline 2016 Entrepreneurs & 3 \\
\hline 2016 Others & 4,13 \\
\hline 2017 Entrepreneurs & 3,67 \\
\hline 2017 Others & 3,95 \\
\hline 2018 Entrepreneurs & 2,9 \\
\hline 2018 Others & 3,88 \\
\hline
\end{tabular}

* significant according to specialization

C04: The people working for government agencies are competent and effective in supporting new and growing firms.

Source: Authors' calculations
Entrepreneurs are more critical than other specialization $(p=0,026)$ about whether people working for government agencies are competent and effective in supporting new and growing firms.

\subsubsection{On Education \& Training (covering statements from the EFC on education at school and post-school stage)}

Statements regarding whether teaching in primary and secondary education encourages creativity, selfsufficiency, and personal initiative $(p=0,002)$; whether it provides adequate instruction in market economic principles $(p=0,003)$ and adequate attention to entrepreneurship and new firm creation $(p=0,003)$, entrepreneurs graded lower compared to other specialization. The same applies for colleges and universities $(p=0,008)$ as well as for the vocational, professional, and continuing education systems $(p=0,068)$.

Table 9. Mean values of Education and Training statements' evaluation /2 way ANOVA/Scheirer-Ray-Hare test

\begin{tabular}{|c|c|c|c|c|c|}
\hline & D01 & D02 & D03 & D04 & D06 \\
\hline Entrepreneurs & $2,03^{*}$ & $2,01^{*}$ & $1,82^{*}$ & $2,75^{*}$ & $3,18^{*}$ \\
\hline Others & 2,68 & 2,59 & 2,36 & 3,41 & 3,66 \\
\hline 2015 & 2,05 & 2,03 & 1,73 & 3,2 & 3,05 \\
\hline 2016 & 2,7 & 2,45 & 2,27 & 3,3 & 3,56 \\
\hline 2017 & 2,38 & 2,47 & 2,31 & 3,04 & 3,62 \\
\hline 2018 & 2,59 & 2,51 & 2,25 & 3,08 & 3,71 \\
\hline 2015 Entrepreneurs & 2,06 & 1,69 & 1,5 & 2,94 & 2,73 \\
\hline 2015 Others & 2,04 & 2,26 & 1,91 & 3,38 & 3,25 \\
\hline 2016 Entrepreneurs & 2 & 2,06 & 1,88 & 2,81 & 3,23 \\
\hline 2016 Others & 3,17 & 2,71 & 2,54 & 3,62 & 3,75 \\
\hline 2017 Entrepreneurs & 2,17 & 2,33 & 2,28 & 2,89 & 3,8 \\
\hline 2017 Others & 2,54 & 2,58 & 2,33 & 3,17 & 3,5 \\
\hline 2018 Entrepreneurs & 1,83 & 1,92 & 1,5 & 2,25 & 2,92 \\
\hline 2018 Others & 2,93 & 2,78 & 2,59 & 3,48 & 4,08 \\
\hline
\end{tabular}

* significant according to specialization

D01: Teaching in primary and secondary education encourages creativity, self-sufficiency, and personal initiative.

D02: Teaching in primary and secondary education provides adequate instruction in market economic principles.

D03: Teaching in primary and secondary education provides adequate attention to entrepreneurship and new firm creation.

D04: Colleges and universities provide good and adequate preparation for starting up and growing new firms.

D06: The vocational, professional, and continuing education systems provide good and adequate preparation for starting up and growing new firms.

Source: Authors' calculations 


\subsubsection{On R\&D Transfer}

Table 10. Mean values of $R \& D$ Transfer statements' evaluation /2 way ANOVA-Scheirer/Ray-Hare test

\begin{tabular}{ll}
\hline & E04 \\
\hline Entrepreneurs & $3^{*}$ \\
\hline Others & 3,65 \\
\hline 2015 & 3,58 \\
\hline 2016 & 3,35 \\
\hline 2017 & 3,36 \\
\hline 2018 & 3 \\
\hline 2015 Entrepreneurs & 3 \\
\hline 2015 Others & 2,96 \\
\hline 2016 Others & 2,93 \\
\hline 2017 Entrepreneurs & 3,62 \\
\hline 2017 Others & 3,65 \\
\hline 2018 Entrepreneurs & 3,62 \\
\hline 2018 Others & 2,17 \\
\hline
\end{tabular}

* significant according to specialization

E04: There are adequate government subsidies for new and growing firms to acquire new technology.

Source: Authors' calculations

Entrepreneurs gave lower grades in evaluating if there are adequate government subsidies for new and growing firms to acquire new technology $(p=0,004)$.

\subsubsection{On Commercial and Professional Infrastructure}

Table 11. Mean values of Commercial \& Professional Infrastructure statements' evaluation /2 way ANOVA/ Scheirer-Ray-Hare test

\begin{tabular}{ll}
\hline & $\mathrm{F} 02$ \\
\hline Entrepreneurs & 3,4 \\
\hline Others & 3,16 \\
\hline 2015 & $2,97+$ \\
\hline 2016 & 3,31 \\
\hline 2017 & 4 \\
\hline 2018 & 2,64 \\
\hline 2015 Entrepreneurs & 3 \\
\hline 2016 Entrepreneurs & 2,96 \\
\hline 2016 Others & 3,88 \\
\hline 2017 Entrepreneurs & 2,91 \\
\hline 2017 Others & 4,22 \\
\hline 2018 Entrepreneurs & 3,83 \\
\hline 2018 Others & 1,91 \\
\hline
\end{tabular}

+ significant according to years

F02: New and growing firms can afford the cost of using subcontractors, suppliers, and consultants.

Source: Authors' calculations
Regarding the statements 'New and growing firms can afford the cost of using subcontractors, suppliers, and consultants', differences exist according to time $(p=0,029)-$ scores have been growing since 2015 and then dropped in 2018.

\subsubsection{On Internal Market Burdens or Entry Regulation (market openness)}

Table 12. Mean values of Internal Market Burdens or Entry Regulation statements' evaluation /2 way ANOVA/ScheirerRay-Hare test

\begin{tabular}{lll}
\hline & $\mathrm{G} 05$ & $\mathrm{G} 06$ \\
\hline Entrepreneurs & $2,07^{*}$ & $2,93^{*}$ \\
\hline Others & 3,07 & 3,34 \\
\hline 2015 & 2,79 & 3,31 \\
\hline 2016 & 3,1 & 3,41 \\
\hline 2017 & 2,8 & 3,08 \\
\hline 2018 & 3,03 & 2,94 \\
\hline 2015 Entrepreneurs & 2,69 & 3,3 \\
\hline 2016 Entrepreneurs & 2,87 & 3,31 \\
\hline 2016 Others & 2,47 & 3,79 \\
\hline 2017 Entrepreneurs & 3,5 & 2,8 \\
\hline 2017 Others & 2,47 & 3,35 \\
\hline 2018 Entrepreneurs & 3,04 & 2,67 \\
\hline 2018 Others & 3,33 & 2,96 \\
\hline
\end{tabular}

* significant according to specialization

G05: New and growing firms can enter markets without being unfairly blocked by established firms.

G06: The anti-trust legislation is effective and well enforced.

Source: Authors' calculations

Related to market openness, entrepreneurs are significantly less satisfied with following statements - 'New and growing firms can enter markets without being unfairly blocked by established firms' $(p=0,072)$ and for 'The anti-trust legislation is effective and well enforced' $(p=0,08)$. It is especially visible in evaluating anti-trust legislation, where the score dropped for eleven percent from 2015 to 2018. 


\subsubsection{On Physical Infrastructure}

Table 13. Mean values of Physical Infrastructure statements' evaluation / 2 way ANOVA/Scheirer-Ray-Hare test

\begin{tabular}{lll}
\hline & $\mathrm{H} 01$ & $\mathrm{H} 02$ \\
\hline Entrepreneurs & $5,33^{*}$ & 6,29 \\
\hline Others & 6,15 & 6,78 \\
\hline 2015 & $6,48+$ & $6,98+$ \\
\hline 2016 & 5,98 & 6,7 \\
\hline 2017 & 5,8 & 6,62 \\
\hline 2018 & 5,05 & 6 \\
\hline 2015 Entrepreneurs & 5,88 & 7,04 \\
\hline 2015 Others & 6,88 & 6,92 \\
\hline 2016 Entrepreneurs & 5,81 & 6,44 \\
\hline 2017 Entrepreneurs & 6,08 & 6,88 \\
\hline 2017 Others & 5,28 & 6,22 \\
\hline 2018 Entrepreneurs & 6,22 & 6,92 \\
\hline 2018 Others & 4,08 & 4,91 \\
\hline
\end{tabular}

* significant according to specialization

+ significant according to years

H01: The physical infrastructure (roads, utilities, communications, and water disposal) provides good support for new and growing firms.

H02: It is not too expensive for a new or growing firm to get good access to communications (phone, Internet, etc.).

Source: Authors' calculations

In evaluating if the physical infrastructure (roads, utilities, communications, waste disposal) provides good support for new and growing firms, entrepreneurs on average gave lower scores $(p=0,02)$ with decreasing trend over time $(p=0,007)$. The drop in scores is 22 percent from 2015 to 2018. Also, for the statement 'It is not too expensive for a new or growing firm to get good access to communications (phone, Internet, etc.)', grades fall over time $(p=0,07)$. Fall in scores are 14 percent from 2015 to 2018.

\subsubsection{On Cultural and Social Norms}

Table 14. Mean values of Cultural and Social Norms statements' evaluation / 2 way ANOVA/Scheirer-Ray-Hare test

\begin{tabular}{ll}
\hline & 105 \\
\hline Entrepreneurs & $2,43^{*}$ \\
\hline Others & 3,03 \\
\hline 2015 & 2,9 \\
\hline 2016 & 2,98 \\
\hline 2018 & 2,8 \\
\hline 2015 Entrepreneurs & 2,5 \\
\hline 2015 Others & 3 \\
\hline 2016 Entrepreneurs & 2,83 \\
\hline 2016 Others & 2,62 \\
\hline 2017 Entrepreneurs & 3,21 \\
\hline 2018 Entrepreneurs & 2,17 \\
\hline 2018 Others & 3,3 \\
\hline
\end{tabular}

* significant according to specialization

105: The national culture emphasizes the responsibility that the individual (rather than the collective) has in managing his or her own life.

Source: Authors' calculations

Entrepreneurs gave lower scores in evaluating does the national culture emphasizes the responsibility of the individual (rather than the collective) in managing his or her own life $(p=0,007)$. 


\section{DISCUSSION}

Our findings reveal that quality of the national entrepreneurship conditions in Croatia is far from satisfactory. Croatia's scores for national entrepreneurship framework conditions are all but two (Internal Market Dynamics and Physical Infrastructure) in the range of inadequate quality (below score 5 which is the threshold point between inadequate and adequate quality), in the observed period. Even if those two conditions could be considered as strengths of Croatia's national entrepreneurship environment, their strength is deteriorating (with the highest negative rates of changes in average scores in 2015-2018). Experts' scores for all other conditions are either decreasing or floating around its level, which is below the neutral point (score 5). In the observed time (2015-2018) the most of conditions are deteriorating - only two conditions (Entrepreneurial Finance and Entrepreneurial Education at the School Stage) are showing annual growth in perceptual scores, but even with such positive changes, the quality of those conditions are still inadequate (below 5). The deteriorating quality of the national entrepreneurship conditions keeps Croatia at the bottom in the groups of countries to which Croatia belongs according to the development criteria (high-income countries) and political criteria (European Union). Only one condition (Internal Market Dynamics) is scored slightly above scores compared to respective scores in both groups of countries (in 2018, Table 5).

Such stable but unfavourable feature of Croatia's national entrepreneurship conditions raises concerns and indicates that policy interventions are not effective, or not existent at all. Those findings open potential new research questions: (1) how such context is related to entrepreneurial activity (specifically focused on starting a venture based on recognized opportunity and on entrepreneurs with ambitions to grow innovative ventures); (2) if policy interventions were implemented, how they contributed to reverse inadequate status of specific conditions into supportive context for entrepreneurial activity - are there any monitoring and evaluation activities, which indicators are used; (3) what is a system's feature of the national entrepreneurship conditions (interlinkages among specific conditions).

Both hypotheses are partially supported by the findings of our study. In concern to our first hypothesis, we explored how different is the perception of EFCs between experts of different specialization, grouped as those who are/were entrepreneurs and all others (those who are investors, educators, researchers, consultants, policy makers, etc.). Our study finds that experts with entrepreneurial background have different perception about statements used to build a construct presenting a specific national entrepreneurship condition. They perceive five out of six statements in the Entrepreneurial Education and Training (at school stage and tertiary level) constructs less favourably than other group of experts. In other components there are one to two statements for which differences in perceptions are significant (Entrepreneurial Finance; Market Openness, Government Entrepreneurship Programs, R\&D transfer, Internal Market Burdens). In other components, the differences in perception related to any statement are not significant comparing groups according to specialisation. Findings are signalling the general agreement on the poor quality of the EFCs in Croatia.

Our second hypothesis about variations in perception along the time is also partially supported Significantly different perceptions are found in evaluation of three out of eight statements describing the Entrepreneurial Finance component across different years. Even the perception of the availability and affordability of the access to physical infrastructure is deteriorating (and it is one of two conditions recognized as a strength of Croatian entrepreneurship environment). In other words, there is consistent perceptual agreement on insufficiency of EFCs in Croatia during 2015-2018.

Besides time perspective, which provides insights in the evolution of perceptions on the quality of the national entrepreneurship conditions, the differences in perceptions among experts' groups are very challenging value adding information. Our study indicates that experts' perceptions on the supportive / hindering capacity of the sub-components which are the building blocks of the entrepreneurship framework conditions are stable across their specializations over the observed period.

Overall, in evaluating eighteen statements with statistical significance, in fourteen cases entrepreneurs are giving lower scores than other experts (only in Entrepreneurial Finance and Commercial and Professional Infrastructure there are three statements evaluated above other experts' scores, and one statement with equal level of scores in Entrepreneurial Finance). It opens a question why such pattern of differences in perception on quality of EFCs exists - and how people (policy makers, educators, researchers...) responsible for designing the specific EFC and coherence of the whole national entrepreneurship environment should react.

Experts associated with other types of specializations (policy makers, educators, investors, service providers) tend to have more favourable perception on the EFCs. This particularly holds for the perception 
of entrepreneurship education. While entrepreneurs perceive that education system does not develop entrepreneurial competence in young people, the other specialists seem to think differently. In order to have efficient national entrepreneurship environment, these perceptual differences need to be recognized and communicated. Awareness of the differences enables stakeholders (such as policy makers, investors, educators, professional services providers) to engage in the dialog and search for better solutions. Better understanding of each other's perspective may lead to more focused efforts to bridge these differences. However, our findings did not provide clear perceptual patterns (neither diverging, nor converging), both, between experts with entrepreneurial experience and those without it, as well as across years.

Like any other study, our research has limitations. Firstly, our insights are based on the case of Croatia; therefore, they cannot be generalized. However, we assume that any country participating in GEM survey may have interest to check strengths and weaknesses of its entrepreneurial framework conditions by using a research approach as one presented in this study. It could provide better understanding of the contextual differences relevant for entrepreneurial activity, across countries. Secondly, our study distinguishes only two groups of experts according to their entrepreneurial (actual or prior) experience. Further study may include each group of experts separately, as well as age and years of expertise in order to test differences according those criteria. Thirdly, probably longer observation period would provide better insights in trends and patterns, as well as redundancy effect in perceiving changes. It could contribute to the methodological discussion on definition of experts and time redundancy in observing changes.

\section{CONCLUSION}

Our study contributes to the ongoing debate about the main components that create nurturing environment for entrepreneurial activities, as well as to the discussion on the methodology of surveying its hindering / supporting features. Based on the GEM data on national entrepreneurship environment for Croatia, the perceptual scores differentiate among different statements that are part of the constructs presenting different entrepreneurship conditions. Significant differences are in all cases (but three) connected to professional affiliations, except in the case of Professional Infrastructure, where significant differences are related to the time. The study revealed that experts who have actual or prior entrepreneurial experience perceive and assess contextual factors differently in comparison to specialists without entrepreneurial experience. Such information enables better targeting of the policies, finances, social, educational or professional support. Similarly, changes in the entrepreneurial policies, programs, availability and affordability of the entrepreneurial finance, education, $R \& D$ transfer, building professional and physical infrastructure, and cultural values need time to gain momentum and show the impact on entrepreneurial activity as well as on expert's perception. This study provides empirical evidence on the dependency of perception of national entrepreneurship conditions across time and stakeholder's area of specialization. Change in the actual environment, or merely the perception of the environmental conditions is a lengthy and complex process of building consensus between different stakeholders such as policy makers, entrepreneurs, educators, researchers, investors, professional service providers. Understanding these differences and understanding the sources of potential convergence or divergence in perception on quality of specific condition as well as on the system's feature of the national entrepreneurship environment might contribute to building better institutions and capacity to sustain entrepreneurship, particularly high growth and innovation driven entrepreneurial ventures.

In order to build a pool of knowledge how nurturing national entrepreneurship environment can sustain its supportive feature, our findings are call for further research. Identified limitations of implemented research ask for better definition of being an expert for the national entrepreneurship environment, for larger sample of experts (by cumulating number of experts involved in three/five years of survey), and by taking longer time frame with three to five measuring points as a basis for implementing the research.

\section{REFERENCES}

Alvarez, C., Urbano, D., Coduras, A. and Ruiz-Navarro, J. 2011. Environmental conditions and entrepreneurial activity: a regional comparison in Spain. Journal of Small Business and Enterprise Development. 18(1): 120-140.

Alvarez, C., Urbano, D. and Amorós, J. E. 2014. Gem Research: Achievements and Challenges. Small Business Economics. 42(3): 445-465.

Amorós, J. E., Bosma, N. and Levie, J. 2013. Ten years of Global Entrepreneurship Monitor: Accomplishments and prospects. International Journal of Entrepreneurial Venturing. 5(2): 120-152.

Andonova, V., Nikolova, M. S. and Dimitrov, D. 2019. Entrepreneurial Ecosystems in the Balkan Peninsula. In: 
Entrepreneurial Ecosystems in Unexpected Places, edited by Andonova, V., Nikolova, M.S., \& Dimitrov, D, 17-55, Cham Switzerland: Palgrave Macmillan.

Audretsch, D. B. and Belitski, M. 2017. Entrepreneurial ecosystems in cities: establishing the framework condition. Journal of Technology Transfer. 42 (5): 1030-1051.

Autio, E. and Acs, Z. 2010. Intellectual property protection and the formation of entrepreneurial growth aspirations. Strategic Entrepreneurship Journal, 4(3), 243-251.

Autio E., Kenney, M., Mustar, P., Siegel, D. and Wright, M. 2014. Entrepreneurship innovation: The importance of context. Research Policy. 43(7): 1097-1108.

Bosma, N., Hill, S., lonescu-Sommers, A., Delley, D., Levie, J. and Tarnawa, A. 2020. Global Entrepreneurship Monitor - Global Report 2019/2020. UK London: GERA.

Bosma, N. and Kelley, D. 2019. Global Entrepreneurship Monitor - Global Report 2018/2019. Chile: Babson.

Chepurenko, A. 2017. Entrepreneurial Activity in PostSocialist Countries: Methodology and Research Limitations. Foresight and STI Governance. 11(3): 11-24.

Correia, A., Silva, E. C., Lopes, I. C. and Braga, A. 2016. MANOVA for distinguishing experts' perceptions about entrepreneurship using NES data from GEM. In AIP Conference Proceedings, 1790(1) 140002

De Clercq, D. D. and Arenius, P. 2006. The Role of Knowledge in Business Start-up Activity. International Small Business Journal. 24(4): 339-358.

De Clercq, D., Lim, D. and Oh, C. H. 2013. Individual-Level Resources and New Business Activity: The Contingent Role of Institutional Context. Entrepreneurship Theory and Practice. 37(2): 303-330.

DiMaggio, P. 1998. The New Institutionalisms: Avenues of Collaboration. Journal of Institutional and Theoretical Economics. 154 (4): 696-705.

Fellnhofer, K., and Kraus, S. 2015. Examining attitudes towards entrepreneurship education: a comparative analysis among experts. International Journal of Entrepreneurial Venturing. 7(4): 396-411.

Felzensztein, C., Gimmon, E. and Aqueveque, C. 2013. Entrepreneurship at the Periphery: Exploring Framework Conditions in Core and Peripheral Locations. Entrepreneurship Theory and Practice, 37(4): 815-835.

Hechavarría, D. M. and Ingram, A. E. 2019. Entrepreneurial ecosystem conditions and gendered national-level entrepreneurial activity: a 14-year panel study of GEM. Small Bus Econ 53:431-458.

Kitsios, F. and Sitaridis, I. 2017. An application of non-weight MCDM for the evaluation of GEM entrepreneurial ecosystems. In Proceedings of 6th International Symposium and 28th National Conference on Operational Research, Thessaloniki, Greece, pp.35-39.

Lee, L. and Wong, P. K. 2004. Cognitive Divergence among Entrepreneurship National Experts: Analysis of Gem
Data 2000-2003. Babson College, Babson Kauffman Entrepreneurship Research Conference (BKERC).

Levie, J. and Autio, E. 2008. A theoretical grounding and test of the GEM model. Small Business Economics, 31: 235-263.

Liñán, F., Santos, F. J. and Fernández, J. 2011. The influence of perceptions on potential entrepreneurs. International Entrepreneurship and Management Journal. 7:373-390.

North, D. C. 1990. Institutions, Institutional Change and Economic Performance. Cambridge, UK: Cambridge University Press.

North, D. C. 2005. Introduction to Understanding the Process of Economic Change in, Understanding the Process of Economic Change, Princeton, USA: University Press.

Reynolds, P. D., Hay, M., Bygrave, M.D. and Autio, E. 2000. Global Entrepreneurship Monitor: Executive Report. Babson/London: Kauffman Centre for Entrepreneurial Leadership at the Ewing Marion Kauffman Foundation.

Sampaio, A., Correia, A., Braga, V. and Braga, A. M. 2018. The impact of entrepreneurship framework conditions in total early-stage entrepreneurship activity: an international approach. International Journal of Knowledge-Based Development- 9(3: 244-260.

Savosh, K. 2019. Innovation on worldwide businesses in the period 2011-2017: Panel data analysis on the impact of the business environmental factors. Bragança :Instituto Politécnico de Bragança, doctoral dissertation

Segui-Mas, E., Jimenez-Arribas, I. and Tormo-Carbo, G. 2018. Does the Environment Matter? Mapping Academic Knowledge on Entrepreneurial Ecosystems in GEM. Entrepreneurship Research Journal, 9(2) published online May 31. https://www.degruyter.com/view/journals/ erj/9/2/article-20170170.xml (accessed June 7, 2020).

Silva, E. C., Correia, A. and Duarte, F. 2018. How Portuguese experts' perceptions on the entrepreneurial framework conditions have changed over the years: A benchmarking analysis. AIP Conference Proceedings. 2040 (1):110005.

Singer, S., Šarlija, N., Pfeifer, S. and Oberman Peterka, S. 2019. Što čini Hrvatsku (ne) poduzetničkom zemljom - Gem Hrvatska 2018. Zagreb, Hrvatska: CEPOR.

Spigel, B. 2016. Developing and governing entrepreneurial ecosystems: the structure of entrepreneurial support programs in Edinburgh. Scotland. Int. J. Innovation and Regional Development. 7(2): 141-160.

Stam, E. 2015. Entrepreneurial Ecosystems and Regional Policy: A Sympathetic Critique. European Planning Studies. 23(9): 1759-1769.

Stam, E. and Spigel, B. 2016. Entrepreneurial Ecosystems, Working Papers No 16-13, Utrecht School of Economics

Sternberg, R. Bloh, J. and Coduras, A. 2019. A new framework to measure entrepreneurial ecosystems at the regional level. Zeitschrift für Wirtschaftsgeographie. 63(2-4): 103-117. 
Teixeira, S., Casteleiro, C., Rodrigues, R. and Guerra, M. 2018. Entrepreneurial intentions and entrepreneurship in European countries. International Journal of Innovation Science. 10(1): 22-42.

Terjesen, S. and Amorós, E. J. 2010. Female Entrepreneurship in Latin America and the Caribbean: Characteristics, Drivers and Relationship to Economic Development. The European Journal of Development Research. 22(3): 313-330.

Thurik, R. and Wennekers, S. 2004. Entrepreneurship, small business and economic growth. Journal of Small Business and Enterprise Development. 11(1): 140-149.
Tominc, P. and Rebernik, M. 2007. Growth aspirations and cultural support for entrepreneurship: A comparison of post-socialist countries. Small Business Economics. 28(2): 239-255.

Verheul, I., Van Stel, A. and Thurik, R. 2006. Explaining female and male entrepreneurship at the country level. Entrepreneurship \& Regional Development. 18(2): 151-183.

World Bank (2020). https://data.worldbank.org/indicator/ NY.GDP.MKTP.KD.ZG?locations=HR (accessed September $5,2020)$. 